\title{
Debt, Money, and Public Finance
}

\author{
Richard E. Wagner
}

A government can finance its activities in four ways. It can tax. It can borrow. It can create money. And it can generate revenue through its operation of enterprises. ${ }^{1}$ These days, taxation is widely regarded as the primary source of state revenue, and this primacy is generally accepted as proper. It is quite common for contemporary authors to cite Adam Smith's four canons of taxation, which he articulated in 1776 in the Wealth of Nations. These canons held that taxes should be levied in proportion to property, should be certain and not arbitrary, should be convenient to pay, and should be economical to administer for both the taxpayer and the state. Furthermore, Smith thought that taxation ideally should be the sole source of state revenue. He preceded his discussion of tax canons with an argument that the state should abolish its holdings of property, thereby relinquishing any revenue it derives from those holdings. Modern states, of course, have not followed Smith's advice in this respect, and have proven ready to accept revenue from nearly any source.

While Smith's vision of a state financed predominately by taxation is second nature to contemporary fiscal scholars, it has not always been this way, either in theory or in practice. In 1760, Johann Heinrich Gottlob von Justi articulated a quite different vision of state finance in Natur und Wesen der Staaten. Taxation was a last resort instrument of public finance. For Justi and the Cameralist authors generally, states were to be financed in the first instance through revenues generated from state enterprises and lands. Justi argued that 
ideally states would not tax at all, and would derive all of their revenue from their enterprises and lands. Taxation was a secondary option only, and one, moreover, that was more strictly limited in Justi's canons than in Smith's. Justi's canons covered all the territory covered by Smith's canons, and more. Justi also held that a tax should never deprive a taxpayer of necessaries or cause him to reduce his capital to pay the tax, nor should a tax ever harm the welfare of taxpayers or violate their civil liberties. This Cameralist principle of public finance, moreover, received practical implementation throughout the central European lands where the cameralists were influential, as illustrated by the much greater fiscal significance of enterprise revenues in the cameralist lands, where those revenues generally provided the majority of state revenues. ${ }^{2}$

This difference between Justi and Smith reflects one of the important orienting principles of the cameralists, namely, that the state acts as a participant within the society and its economic order. The cameralist advice on the use of state budgets and other policy instruments to promote the well being of the state and its subjects took place within a presumption that the state itself was located inside the economic order and not outside it. The state is but another participant within the economic order of a society. Civil society and the state are nonseparable and co-emergent. This treatment of the state in relation to civil society contrasts sharply with various contemporary constructions where state and society are treated as autonomous and independent from each other. In this alternative construction, the state intervenes into civil society and its processes. This distinction between the state as participating within the economic order and 
the state as intervening into the economic order, has numerous implications and ramifications, one of which concerns the generation of state revenues. The cameralist ideal, recognizing that practice rarely if ever conforms fully to ideals, was the state as a peaceful and productive participant within the economic order. The Smithian ideal was the state as a violent force for intervention into the economic order. It is perhaps no wonder that Joseph Schumpeter (1954, p. 172) described Justi as "A. Smith . . . with the nonsense left out."

Geoffrey Brennan and James Buchanan (1980) construe the state as a revenue-maximizing beast, a leviathan. While the leviathan of the Bible lived in the sea, it is easy enough to imagine it as living on the land. Smith's maxims for taxation are a recipe for living with the leviathan by doing such things as clipping the beast's nails and filing down its teeth. A beast it will always be, and the objective of tax maxims should be to limit the damage the beast causes. Justi's maxims for taxation, in conjunction with his preference for enterprise revenues over taxation, represent a contrary intellectual orientation that would seek to domesticate the beast. To be sure, some would argue that genuine domestication is impossible.

Regardless of the relative standing of taxes and enterprises as sources of state revenue, fiscal scholars have generally regarded borrowing and money creation as secondary forms of public finance. Indeed, borrowing and creating money have often been characterized as instruments of extraordinary public finance, in contrast to taxes (and, once upon a time, enterprise revenues) as being instruments of ordinary public finance. Borrowing and creating money are 
not options different from taxation, but are different forms of taxation. A state that borrows is reducing current tax extractions in exchange for making a commitment to impose higher tax extractions in the future to service and amortize the debt. Borrowing is simply deferred taxation. Money creation is also a form of taxation, though one that is collected currently and not in the future. A state could impose a tax directly on money. Such a tax, however, would be costly to implement and enforce. It is cheaper for a state to tax money indirectly by debasing its real value through inflating the supply of money.

This essay explores various issues and controversies regarding borrowing and money creation as instruments of public finance. It starts by reviewing a controversy about public debt that that started shortly after the end of World War II. This controversy centered on the ability of public debt to transfer the burden of current state spending from current taxpayers to future taxpayers. A review of this controversy will help to set up the subsequent examination of debt and money as instruments of public finance. This analysis will pay particular attention to the institutional framework within which governments are constituted and borrowing occurs. It matters a great deal analytically whether governments are autocratic or democratic, as well as whether there is freely competitive banking or state-imposed central banking.

\section{Postwar Controversy over the Burden of Public Debt}

The postwar period has seen a sequence of controversies about the locus of the burden of government expenditures that are financed by public debt. The 
classical theory of public debt held that state borrowing allowed the cost of current public spending to be shifted forward to the time when the debt was amortized. A good deal of argument took place over the propriety of such an intertemporal shift in tax burden. If future taxpayers are not represented when public debt is chosen, present taxpayers might choose too much public debt because this shifts some of the burden of public spending from present to future taxpayers. On the other hand, current public spending might provide significant benefits for future taxpayers. In this case, public debt could allow tax burdens to be placed more fully on the beneficiaries of public spending. The use of public debt to finance wars, for instance, was generally thought to be desirable because it allowed the present generation, which fought the war, to shift some of the burden onto future generations, which received benefits from the battles fought by the current generation. In contrast, the use of public debt to finance government consumption was opposed on the grounds that it would allow a current generation to shift the burden of their own state-provided enjoyment onto future generations.

While the classical theory allowed for public debt, it also placed strong limits on its use, due to the perceived opportunities for the exploitation of future taxpayers by current taxpayers. The classical theory of public debt was challenged by the Keynesian formulations that were ascendant in the early postwar period. The classic statement of the Keynesian position was set forth in Abba Lerner (1948). There was a straightforward denial that public debt could shift the burden of public expenditure forward in time, thereby undercutting the 
classical warning against public debt. Whether a war is financed by current taxation or by borrowing, the resources expended to fight the war are sacrificed in the present and not in the future. Indeed, it makes no difference whether public debt is used to finance public capital creation or current consumption. In either case, the cost of public spending is necessarily borne in the present when it is incurred. The subsequent servicing of national debt will require the imposition of taxes to pay interest and to amortize the debt. Those tax payments, however, do not represent any bearing of cost stemming from past decisions, for that cost was borne in the past when the expenditures were made.

Present taxes to cover interest on and amortization of the debt are simply transfer payments, as distinct from being genuine opportunity costs. Today's public debt entailed a burden yesterday when it was created, but the service of that debt today is only a transfer payment and not a genuine burden. If public debt involves any current burden, it must be due to some secondary effect of the debt in reducing the stock of capital from what it might otherwise be. This effect was generally thought to be conceivable to the extent that government borrowing led to increased interest rates. To the extent that such an effect might operate, public debt could involve a secondary burden upon present taxpayers. The primary burden, however, was borne in the past, when the debt-financed expenditures were made. The only exception to this proposition about the primary burden of public debt would arise to the extent that public debt was held externally by citizens of foreign lands. To the extent public debt was held internally by domestic nationals, however, public debt places no burden on future 
taxpayers, and debt service is simply a transfer payment between bondholders and future taxpayers.

This Keynesian rejection of the classical, cost-shifting thesis about public debt was countered sharply in James Buchanan (1958). Buchanan advanced an alternative articulation of the classical argument that debt finance allows the burden of public expenditure to be shifted forward in time. Buchanan, moreover, was referring to the primary burden, independently of any secondary impacts that might operate through capital formation. He further argued that the distinction between internal and external debt was irrelevant because the same implication for cost shifting resulted in either case.

Buchanan did not dispute the Keynesian point that it is impossible to shift resources from the future to the present. The resources that are used to supply governmental activities currently must be taken from what would otherwise be available currently for private use. But this does not mean that borrowing and taxing have the same temporal location of cost. With taxation, costs are clearly borne in the present, just as costs are borne in the present when someone pays cash rather than borrows. But public borrowing creates a strikingly different situation. If a war is financed by public borrowing, the people who buy the bonds provide the revenues required to fight the war. Yet these bondholders do not bear any burden. To the contrary, they have willingly reduced their current consumption to provide the resources for government to fight the war, in exchange for even greater consumption in the future when government services and amortizes the debt. Bondholders have been induced voluntarily to shift their 
intertemporal pattern of consumption, and have thereby secured a preferred state of affairs, and have most certainly not borne any burden. Present taxpayers obviously bear no burden, because the issue of public debt has reduced their taxes from what they would otherwise have been. The burden of the current spending must thus be borne by future taxpayers who must pay to amortize the debt, when they would not have had to make such payments had tax finance been used initially.

Public debt involves a two-part transaction and not just a single transaction between citizens and the state. In one part of the public debt transaction, bondholders agree to pay taxes that would otherwise have been paid by taxpayers. In the other part of the transaction, taxpayers in the future are being committed now to making payments to the bondholders. It is the bondholders when the debt was created who provide the resources necessary to supply the public output in question. But these bondholders bear no burden because they have been compensated for this through the promise of future payments for interest and amortization. And certainly taxpayers in the present cannot have borne any burden, because they secured tax reductions by virtue of the purchase of bonds by bondholders. The burden of debt-financed spending must rest on future taxpayers, which implies that public debt does shift the cost of public spending forward in time.

Just as a Keynes vs. the Classics kind of controversy raged in macro and monetary economics in the postwar period, so did a Keynes vs. the classics kind of controversy rage over public debt. A good deal of this controversy is captured 
in James Ferguson's (1964) collection of essays. Just as the macro and monetary controversies took on a new character with the development of rational expectations and New Classical macroeconomics, so too did the public debt controversies. The sharpest statement of this position was set forth in Robert Barro (1974), though Earl Thompson (1967) articulated a similar position. The New Classical position embraced the classical claim set forth by Buchanan, that public debt allows the burden of public expenditure to be shifted forward in time. Contrary to Buchanan and the classics, though, Barro held that this shifting was of little consequence because of David Ricardo's (1817) proposition about the equivalence of debt and taxes.

For a single person, Ricardian Equivalence is little more than simple arithmetic. One person may pay a $\$ 100$ tax obligation now. Another might pay it by borrowing $\$ 100$ for one year at ten percent. This person's payment of $\$ 110$ in one year is equivalent to the other person's present payment of $\$ 100$. Whichever method of payment is selected, the taxpayer's net worth remains the same. As a simple matter of arithmetic, borrowing and taxing are equivalent in present value terms.

Whether they are also equivalent for the theory of public finance is another matter. Ricardo himself thought that the fiscal effects of debt would differ from those of taxation, with debt promoting public profligacy. Whether the simple arithmetic of Ricardian Equivalence applies politically as well as individually has created considerable controversy. If Ricardian Equivalence does hold in a political setting, public debt will not cause present taxpayers to think they are 
wealthier, because they will take into account the present value of the future tax liabilities that will be necessary to service and amortize the debt. Contrary to Buchanan and the classics, public debt would raise no normative issues of intergenerational equity. Contrary to the Keynesians, the government's budget could not serve as a tool to promote economic stability because an increase in state borrowing would not expand aggregate spending. Public debt would be neither an evil nor a gallant animal, as it rather was simply neutered in the New Classical formulation.

To say that public debt was neutered in one particular analytical formulation is not, of course, to say that it was neutered in reality. The New Classical formulation treats public debt as a form of personal debt and, indeed, treats the state simply as a wealthy individual. The New Classical formulations might thus seem particularly applicable to the conduct of autocratic regimes where state policies are the choices of the autocrat. In democratic regimes, however, state policies are not the choices of some ruler. Rather, they emerge through complex interactions among political participants, and with those interactions being shaped and constrained by some particular institutional framework that governs the relationships among those participants. Despite the universal validity of the arithmetic of Ricardian Equivalence, the fiscal economics of public debt may differ, depending on the particular framework of political and fiscal institutions that are in place. ${ }^{3}$ A shift from taxation to debt would thus be more a micro than a macro matter, and in this respect would be treated as but one instance of a shift in the structure of taxation. Public debt, as taxation 
generally, emerges out of a budgetary process. The central issues about public debt are of the same nature as all other budgetary controversies within a society. Public debt must be located within models of budgetary politics, and when this is done public debt becomes centrally concerned with interest groups and wealth redistribution among current taxpayers. Any intertemporal redistribution becomes incidental to the primary redistribution that lies at the core of the budgetary process. ${ }^{4}$

\section{Autocracy and the Personalization of Public Debt}

Public debt analysis mostly adopts autocracy as its ideal-type state, even if the analysis is not expressed this manner. Such an ideal typical state is implicit in the very treatment of public debt as simply a special case of private debt. To be sure, in the autocratic states of the ancien regime, state accounts and personal accounts were mingled. A state's debts were the debts of a king or prince, and were perhaps a source of concern for creditors as well. All public debt was necessarily held externally, for it would make so sense for a king or prince to borrow from himself. A state could be a net debtor or it could be a net creditor. In either case, though, it would be reasonable to treat the state as a person, though often a particularly large and powerful one. A king's borrowing to fight a war would be analytically indistinguishable from an individual's borrowing to buy a car.

Autocracy provides the simplest institutional framework for the consideration of public debt. There is no significant difference, conceptually 
speaking, between public and private debt in this case. To be sure, the fiscal literature often describes public debt as "sovereign debt." This description conveys the idea that public debt is just a particular form of private debt, where the borrower is especially powerful, which in turn may create some unique situations of borrower-lender relationships that do not arise in typical credit transactions.

Just as a private citizen might borrow in response to some unanticipated decline in income or some unanticipated increase in desired spending, so might a sovereign. For a sovereign, the unanticipated decline in income might correspond to a depression. The unanticipated increase in desired spending might correspond to a desire to go to war. In either case, borrowing is the alternative to an increase in taxes to cover these unanticipated changes in income or expenditure. State borrowing allows a sovereign to achieve a smoother intertemporal pattern of taxation than would be possible otherwise (Barro 1979). There are several possible reasons why an autocrat might be interested in the tax smoothing that borrowing allows. The excess burden of a tax generally rises with the square of the rate of tax. Borrowing and tax smoothing thus leads to a lower excess burden in the aggregate than would result under a regime of a continually balanced budget. A very benevolent autocrat might borrow because he valued the increased welfare of his subjects that resulted from this reduction in excess burden. A non-benevolent autocrat might borrow because this reduction in excess burden lowered the resistance to taxation among his subjects, under the presumption that the intensity of tax 
resistance varied directly with both the excess burden and the amount of taxes extracted.

For an autocrat, as for an individual citizen, public debt affects the timing of expenditure but does not affect net worth. Ricardian Equivalence clearly holds for personal debt. Someone who borrows to buy a car does not become wealthier than he would have been by paying cash. The reduction in cash that would have been required is equivalent to the present value of the liability for amortization payments when the car is financed by borrowing. Loan finance may be preferred to cash finance in some cases, perhaps as illustrated by arguments that loan finance allows the buyer to achieve a smoother time path of total consumption than would be possible with cash finance. But loan finance does not allow someone to escape from the intertemporal budget constraint; consumption may be reduced by a lesser amount now with loan finance, but it will have to be reduced by a greater amount in the future as the debt is amortized.

The Ricardian character of personal loan finance stems from the institutional setting within which credit markets operate, namely a framework of free exchange organized within an institutional framework of property and contract. ${ }^{5}$ Within this institutional framework, a borrower cannot expect his borrowing to increase his net worth. A borrower who held such an expectation would be receiving a gift and not a loan. Lenders won't lend if they believe this will simply transfer their wealth to borrowers. Borrowers must convince lenders to lend, which lenders will do only if they feel confident that those loans will be 
paid. Such institutional practices as credit references and collateral, along with the readiness of the state to enforce credit contracts, generates Ricardian Equivalence as a feature of ordinary credit markets.

A sovereign, however, is not an ordinary participant in a credit market. The sovereign's debt is a personal debt, just as fully as are the debts of other borrowers. The institutional framework is altered when sovereign debt is involved. For one thing, the sovereign cannot be called upon to enforce debt contracts against himself. A lender cannot call upon some external authority to enforce a contract against a sovereign. So long as debt is supplied voluntarily to the sovereign, the sovereign must have generated an expectation of contractual compliance among the lenders. A good deal of the recent literature on political economy has explored methods of commitment and concerns with reputation as a means of generating such expectations among lenders (see, for instance, Bulow and Rogoff (1989), Calvo (1988), Drazen (2000, pp. 101-215), Eaton and Gersovitz (1981), and Grossman and Van Huyck (1988)).

Moreover, contracts of sovereign debt need not be genuinely voluntarily. They can be duressful instead. Someone with wealth may well prefer not to lend to a sovereign, and yet do so anyway in light of what might be the consequences of refusing to lend. In ordinary credit markets, lenders are voluntary creditors. With sovereign debt, however, lenders may well be forced creditors, with a veneer of voluntarism masking the coerced reality that surrounds the loan. Under these circumstances, both borrower and lender may expect the 
transaction to increase the sovereign's net worth and to reduce the lender's net worth.

\section{Democracy and the Intermediary State}

In his famous essay on just taxation, Knut Wicksell (1896, p. 82) complained that the theory of public finance "still rests on the now outdated political philosophy of absolutism. The theory seems to have retained the assumptions of its infancy, in the seventeenth and eighteenth centuries, when absolute power ruled almost all Europe." While the theory of public finance has changed greatly since Wicksell's time, a presumption of political absolutism still makes frequent appearances in theoretical formulations, with the treatment of public debt as sovereign debt being but one illustration among many.

It is sensible to speak of an autocrat as being indebted, just as it is sensible to speak of a person or a corporation as being indebted. For a person or organization to be indebted, there must be some other person or organization to whom the debt is owed. Under these circumstances, it is reasonable for a potential creditor to be concerned with the ability of a potential borrower to repay a loan. It is plausible that someone might become so heavily indebted as to make payment impossible and default unavoidable. Such thinking about the burden of debt servicing is commonly extended to governments, and is expressed in concerns about whether public debt can become so high as to render default likely (see, for instance, Spaventa (1988)). These concerns are 
often expressed in terms of public debt as a share of GDP, and with the degree of concern escalating with increases in the ratio of public debt to GDP.

Such concerns are generally misleading, however, when it comes to democratic debt, particularly when that debt is held internally. Public debt in a democracy is distinct from public debt in an autocracy. An autocrat must borrow from an outsider; autocratic debt must be held externally. While democratic debt can be held externally, a good deal of it is held internally. The limiting case is where all public debt is held internally. In this case the state becomes a form of financial intermediary that organizes and maintains a complex transaction among the citizenry. The state itself is not indebted, but rather it simply manages the debtor-creditor relationships among the citizenry that arise out of the state's budgetary process. A failure of a state to service public debt is a failure of intermediation. It is the same as with a bank. A depositor might not be able to withdraw his deposit because the bank's loans did not perform as well as the bank expected. Financial intermediation, whether organized privately or publicly, might not work fully in congruence with the expectations of those who participate in that intermediation. These concerns about intermediation, however, are not concerns about the volume of intermediation in relation to some measure of aggregate output. Rather they are concerns that are addressed by such matters as the theory of agency.

Suppose an increase in state spending is financed by debt rather than by increased taxation. Had taxation been selected, there would doubtless exist some taxpayers who would prefer to borrow to cover their added tax payments. 
The more widespread this preference, the denser would be the resulting network of market-based credit transactions. Public debt replaces this private network of credit transactions with a state-organized program of financial intermediation. The state serves as an intermediary between that part of the citizenry who are borrowers and that part who are lenders. This resulting substitution of state intermediation for market-based intermediation may be generally beneficial, or it might be beneficial to some and harmful to others. Some of those borrowers might have been willing borrowers while others were forced to do so. The extent of voluntary and forced borrowing will depend on a wide variety of rules and institutions that constitute the political and fiscal process.

The fiscal literature contains two polar types of models or frameworks of democratic governance, which may be described as consensual and factional. The most prominent formulation of consensual democracy in the fiscal literature is Knut Wicksell's (1896) formulation of just taxation, along with the associated literature on the benefit principle of public finance. Within Wicksell's formulation, fiscal choices would be made within a legislature that was selected through proportional representation, with the legislature bound by a voting rule of nearunanimity. A further feature of Wicksell's framework is that proposals to spend would be considered simultaneously with proposals to tax, under a type of generalized earmarking.

There are many models of factional democracy in the fiscal literature. They all involve formulations grounded in a process of subordination and domination, whereby some people gain at the expense of others. One such set 
of models operates with simple notions of majority voting. The archtypical model of majoritarian democracy is one where a winning majority approves larger spending programs because they are able to impose a good share of the cost on the remainder of the citizenry, who do not value the project as highly. Other models of democracy entail processes by which a well-organized and relatively intense minority is able to dominate a poorly-organized and relatively passive majority, as illustrated by the literature on rent seeking (see, for instance, Mitchell and Simmons (1994) and Tullock (1967)).

The analytics of democratic debt differ in important respects, depending on whether a model of consensual or factional democracy is more appropriate. In either case, though, democratic debt differs from sovereign debt, in that it is misleading to speak of the state as being indebted. In a democracy a state can be neither a debtor nor a creditor. The state is rather an intermediary that brings together different parts of the citizenry, though the intermediary may act consensually or factionally depending on the institutional framework.

\section{Consensual Democratic Debt}

The Wicksellian institutional framework is one illustration of a framework whereby fiscal outcomes would reflect generally an underlying consensus among the members of the polity (for further elaboration see Backhaus (1992)). It can be asked under what circumstances in such a polity its members would support debt finance over tax finance. For public debt to arise in a consensually democratic setting, there must exist circumstances under which people would 
prefer to organize debtor-creditor relationships collectively rather than through market processes. Public debt in this instance would represent a nationalization of financial intermediation, or at least that part of intermediation that arises in response to the claims of extraordinary public finance.

Are there circumstances under which it is plausible that there could exist gains from trade from the collective organization of financial intermediation? A necessary condition for this to occur is that collective intermediation is a lower cost alternative to market-based intermediation. This lower cost provides the potential gains from trade through collective intermediation. Whether that potential would actually be realized in practice is a different matter. Nonetheless, the potential for gain requires some cost advantage for collective intermediation. To the extent there is some element of fixed cost that is independent of the size of a transaction, a collective loan potentially can exploit some economy of scale, as de Viti de Marco argues (1936, pp. 377-98).

In this respect, it is often noted that public debt carries a lower interest rate than private debt. Public debt allows people to borrow at the government's borrowing rate, which is lower than what people could obtain through market transactions. The question, though, is whether this difference between public and private borrowing rates truly represents a cost advantage for collective intermediation. Various considerations from theories of economic organization and bureaucracy present reasons for being skeptical about this possible cost advantage. Public loans might carry a lower interest rate than private loans even if collective intermediation is more costly. The interest rate on private loans must 
include the cost of attracting capital into financial intermediation, in competition with other uses of capital. For public loans, or for government generally, there is no explicit cost of capital, even though there is always an opportunity cost of capital. For public loans, the burden of higher cost and greater risk is borne by taxpayers and not by lenders. Unlike the limited liability of corporate shareholders, taxpayers have unlimited liability.

The possibility that the state could serve as an efficient intermediary for the organization of credit transactions in cases of extraordinary public finance cannot be denied. At the same time, however, the interest rate differential between public and private loans cannot be used as evidence in support of the claim that public loans result because the state is an efficient intermediary. Public loans may well result even if the state is an inefficient intermediary, depending on the performance characteristics of various political and fiscal institutions.

To be sure, an argument about economies of scale is not conclusive on this point. Another question concerns whether the liability for subsequent amortization is assigned explicitly at the time the debt is created or is left as a contingency to be determined in subsequent years. In the former case, public debt would operate just as private debt. At the time the debt was created, people would be assigned a schedule of their future liability for amortization. One difficulty with this procedure is that some people may find themselves unable to make their payments in subsequent years. If this happens, the revenues collected will not be sufficient to service the debt. In a corporate setting, the 
shareholders would be liable for this gap between revenues and expenses. If taxpayers in general are to be liable for this gap when it comes to public loans, a taxpayer's liability becomes contingent on future circumstances and is not genuinely determined at the time the debt is created. For any taxpayer at the time public debt is created, future payments for servicing the debt are contingent on future economic circumstances. It is conceivable that something like Wicksellian near-unanimity could obtain in this setting, but the setting for choice would be more complex than normal credit transactions. A taxpayer's liability for a decision to borrow rather than to tax is not specified currently but is contingent on future circumstances. A certain stream of future payments is replaced by some expectation and associated variance. Under normal presumptions about risk aversion, the greater the variance the greater must be the cost advantage for public loans, to make public loans a likely outcome in a consensual fiscal setting.

\section{Factional Democratic Debt}

Even if the institutional framework corresponds to some non-Wicksellian framework of factional democracy, as characterized by various models of rent seeking and rent extraction, Ricardian Equivalence must provide a point of departure for any analysis of public debt. Ricardian equivalence must hold in the aggregate simply as a matter of arithmetic. Such an aggregate condition must not be confused with a proposition of behavioral invariance to particular institutional conditions. Aggregative equivalency does not imply that choices between debt and taxation will be invariant to the institutional setting within which 
such choices are made. The choice between debt and taxation can matter for particular people. Indeed, these differences are central for any effort to understand the creation of public debt in the first place. Different institutional settings may lead to different fiscal and budgetary choices, and with different consequences resulting, despite the underlying constraint implied by Ricardian Equivalence.

To illustrate this point, consider the simple model of budgetary equilibrium that is set forth in James Buchanan (1964). Suppose the government provides a single service financed by a proportional income tax, and with public debt precluded through constitutional provision. All citizens have identical preference patterns and the demand for the public service is characterized by unitary price and income elasticities of demand. In this setting, any voting rule gives the same outcome as unanimity; all citizens agree on the size amount of public output and each pays a tax-price equal to his marginal evaluation of public output.

How might the elimination of the constitutional constraint on public borrowing affect the resulting budgetary outcome? For deficit finance to effect budgetary outcomes, public debt would have to be regarded as a lower cost alternative to taxation by some decisive subset of the population, even if collective intermediation does not have a cost advantage over private intermediation. By virtue of the Ricardian theorem, the aggregate present value of future taxes must equal the amount of the budget deficit. But it does not follow that such present-value equivalence holds across individuals, and if it does not 
hold, the consequences for budgetary choice will depend on the way in which fiscal institutions shape and constrain processes of budgetary choice.

An assumption of full intergenerational altruism has often been used to support Ricardian Equivalence. This assumption converts a model where people have limited lives into one where they live forever and, hence, cannot escape bearing the future consequences of present choices. There is no doubt that strong intergenerational altruism characterizes some family settings, and models of infinite livelihood probably have great descriptive value in these cases. But there is equally no doubt that intergenerational dislike also characterizes numerous family settings. There are simply too many resources involved in family and divorce law, and in dealing with battery, brutality, incest, and the like to argue otherwise. And there is surely a broad spectrum of in-between cases of varying degrees of benignity, indifference, and the like. It is quite plausible to presume that people differ in the degrees to which they carry intergenerational altruism. ${ }^{6}$

When people differ in their intergenerational altruism, borrowing reduces the relative cost of government services to people the weaker is that altruism. In a simple median voter model, the person whose intergenerational altruism is median within the population will control the budgetary choice. The introduction of a deficit financing option will lead to an expansion in the size of government because it reduces the cost of government to the median voter. A new budgetary equilibrium will be established where, for the median voter, the marginal value of added public output equals his marginal cost through deficit 
finance. Consider, for instance, three taxpayers of different ages, which can be characterized in terms of taxpaying life expectancy. The eldest taxpayer has 10 years of taxpaying life expectancy, the middle taxpayer has 20 years, and the youngest taxpayer has 40 years. For each of the three, the alternative to a $\$ 1,000$ tax is to issue public debt in the form of a perpetuity, which requires $\$ 100$ per year to service. The relevant rate of interest is 10 percent. For the youngest taxpayer, the present value of debt finance is $\$ 978$, which is practically the same as taxation. For the eldest person, however, the present value of debt finance is only $\$ 614$. So long as intergenerational altruism is incomplete, public debt becomes systematically less costly with increasing age. Even though negative bequests cannot be left privately, because debts cannot be passed on to heirs, public debt can serve as a means of doing this.

There are other models of collective choice besides the median voter model, and some of these would give descriptively different but analytically similar results. For instance, a ruling political party could be viewed as expanding different tax sources so as to equalize political resistance at the respective revenue margins. ${ }^{7}$ The introduction of a debt option lowers marginal political cost. This leads to deficit finance, and the more fully debt is used the higher becomes the political cost of deficit finance. The political pressures from different revenue sources will be equalized at the relevant political margins, where the future taxes represented by debt finance encounters the same political resistance encountered by present taxes. The Ricardian proposition must hold 
as a condition of political equilibrium, for otherwise there will be a shift in the mix of tax instruments toward those that entail lower political cost.

In any case, public debt becomes a method for transferring wealth among the members of a generation. People with relatively weak bequest motives promote the use of public debt over taxation as a method of increasing their net wealth. People with relatively strong bequest motives suffer a wealth loss through the larger than desired public sector that results. They also recognize that the growth in government debt impinges upon the future well being of their heirs, and so would be predicted to increase their saving in response to the creation of public debt. The creation of public debt does not increase aggregate wealth, but it does increase wealth for some people who are influential at the margins of budgetary choice, while reducing wealth for those who are on the losing side.

Efforts have also been made to explain public debt as a strategic instrument within a model of partisan political competition (see, for instance, Persson and Svensson (1989), Tabellini and Alesina (1990), and Alt and Lowrey (1994)). So long as it is presumed that a government will not repudiate public debt, save for the repudiation of real value that can occur through inflation, an increase in public debt today can restrict the budgetary options of the party in power tomorrow. The party in power may prefer a budget mix that is heavily weighted toward projects of capital construction, while the party out of power may prefer a mix that is heavily weighted toward spending on welfare-like measures. Even if the party in power prefers to operate with a balanced budget, it may enact 
deficits if it thinks the opposition party has a good chance of coming to power. The budgetary claims to service the debt will impinge upon the ability of the other party to support welfare-like measures. To be sure, the ability of public debt to serve such a strategic purpose depends on the presumption that debt repudiation is not an option. The prospects for repudiation in such a framework would, in turn, seem to depend on the relative concentration of debt holders in one party or the other. If the debt is held largely by supporters of the party in power, debt repudiation by the opposition party could simultaneously expand the options for supporting welfare-like measures and impose a wealth loss on supporters of the other party.

\section{Money, Seigniorage, and Public Debt}

Public debt may serve as a form of deferred taxation; however, it may also serve instead as a current tax on money balances. Under contemporary institutions, the monetary base is expanded when a central bank buys public debt. Similarly, the monetary base is reduced by central bank sales of public debt. The effects of transactions in public debt depend on who does the transacting. If debt transactions involve the central bank, monetary policy is being conducted because the monetary base is being changed. If private citizens are doing the transacting, asset portfolios are being changed but the monetary base is not affected. A government issue of public debt that is purchased by private citizens has no monetary impact. By contrast, an issue of 
public debt that leads the central bank to increase its holding of public debt increases the supply of money.

Public debt is thus fiscally schizophrenic. Its economic character and impact depends on who is buying or selling it. One day, transactions in public debt may be a means of taxing money balances. On another day, transactions in public debt may be a collective act of financial intermediation that allows a good number of people to defer their income taxes. Which it is, and when, depends on the type of monetary institutions that are in place within a society. ${ }^{8}$ The contemporary institutional framework of central banking confounds state borrowing and money creation. Free banking as an alternative to central banking would avoid this confounding of debt and money, by creating a clear separation between state borrowing and money creation. A freezing of the monetary base would also avoid this confounding, at the same time would maintain a central bank. In any case, the fiscal analytics of borrowing and money creation would thus depend on both political regime and monetary framework.

While free banking has appeared in a number of historical instances, central banking is clearly a predominant feature of monetary arrangements. There are two broad approaches one might take to explaining the dominance of central banking. One revolves around claims of market failure. These claims are represented by the aphorism that money can't manage itself. The other approach to explaining the dominance of central banking involves processes of political domination. Money may well be able to manage itself through free banking, as Selgin (1988 argues), but it is not allowed to do so because there are 
political profits to be reaped through central banking (Wagner 1986b). While a detailed examination of these contending approaches to explanation are outside the scope of this essay, some brief consideration can be given as to how central banking might serve as an instrument of domination and subordination within a framework of factional democracy.

Central banking allows for some expansion in the government's budgetary capacity, as compared with what that capacity would be under free banking. It does this by creating an instrument of taxation that does not exist with free banking. This instrument is the taxation of people's money balances (Friedman (1971), Selgin and White (1999)). To be sure, it is possible to tax money without central banking. It would be relatively costly to do so, however, as is illustrated historically by various practices where coins were debased as they passed through royal treasuries. With central banking and fiat money, it is nearly costless for the treasury to tax money. An expansion in the nominal stock of money reduces the real value of existing units of money and provides revenue to the central bank in the process.

Whether this revenue generated through inflation accrues to the central bank or the treasury depends on various institutional features that govern the relations between the two. In some places the central bank is located within the treasury, in which case the revenues accrue directly to the treasury. In other places, the central bank has some degree of independence from the treasury. This independence may allow the central bank to use seigniorage for its own purposes. Typically, though, most of the revenues are returned to the treasury in 
what appears to be a voluntary transfer. The degree of central bank independence is a political outcome, and that independence can continue only so long as there is not strong political interest to remove that independence. A "voluntary" return of seigniorage is surely a means of keeping support for nominal independence, and with the central bank securing some seigniorage for its own use. In other words, the central bank can claim some share of seigniorage revenues for its own uses, so long as it raises a satisfactory amount of revenue for the government (Boyes, Mounts, and Sowell (1998) and Toma (1982)).

To be sure, there is some question of the extent to which inflation is pursued directly, as against its being a by-product of the pursuit of other outcomes and the promotion of other interests through government. In the former case, seigniorage is pursued directly as a source of tax revenue. In the latter case, inflation results as an adjustment to other policy measures. Costpush inflation has little merit on purely economic grounds. An increase in prices in particular sectors cannot be a direct source of inflation, because output will expand and prices will fall elsewhere in the economy. However, cost-push inflation may acquire added explanatory power once political processes and interests are taken into consideration (see, for instance, Iversen (1999)). A simple framework could involve unions and a central bank. Unions place a positive value on increases in real wages among members and a negative value on unemployment among members. The central bank evaluates both inflation and unemployment negatively. Increases in real wages that would otherwise increase unemployment might induce the central bank to increase the monetary 
base to reduce the rise in unemployment that would otherwise result. In doing this, the central bank is judging this course of events to be preferable by its own calculus to the course of events that would otherwise result. That alternative course would start with rising unemployment in the unionized sectors, which in turn would induce shifts of labor elsewhere, as well as inspire entrepreneurial efforts to organize lower-priced substitutes for union-produced products.

While central banks are normally associated with changes in the stock of money, they are also heavily implicated in processes of credit allocation. The pattern of credit allocations includes a significant variety of governmental regulations that influence the allocation of credit. In modern democratic states where interest group political processes are woven throughout the economy, credit allocation would seem clearly to offer more scope for a market for legislation to operate than can monetary policy. After all, the stock of moneybased credit is on the order of 10 to 15 times larger than the stock of money. Moreover, credit involves not even a hint of neutrality, but is wholly concerned with individual wealth positions. Governments are involved in numerous ways in altering market-based credit terms and relationships. Usury regulations have, of course, been around for a long time, and more recently a variety of "fairness" regulations have sought to increase the supply of credit to certain racial and income categories.

Consider an effective political desire to increase the credit supplied to some particular interest group. One way this shift in credit can be accommodated is for a reallocation of credit away from other participants. This 
policy measure would be a regulation-imposed form of tax-transfer operation, with the regulatory agency forcing lenders to expand their lending to favored groups, and financing that lending by reducing their lending to unfavored groups. This type of operation is clearly possible, as tax and transfer operations are at the core of interest group processes of political competition.

There is, however, an alternative possibility. The credit expansion to the favored group can be accommodated by the central bank through an expansion in the stock of high-powered money. Such a monetary expansion would reduce the political opposition to the credit reallocation that would otherwise result in the absence of an accommodating monetary policy, principally because the cost of the credit reallocation is shifted away from other interest groups onto the population generally. Monetary policy thus becomes the equilibrating vehicle that accommodates changes in the market for credit that emanates from interest group politics, similar to short-term capital movements serving to create equilibrium in a balance of payments. Credit might drive money within an interest group model of government, because that is where the greatest harvest of political profit lies, even if it is money that drives credit in a liberal market economy.

\section{Concluding Remarks}

The economic analysis of public debt differs depending on the presumed political setting. It may be reasonable to characterize public debt choices within an authoritarian regime as being made by a single mind, but such a characterization is surely inapt for democratic regimes. To be sure, even in such 
regimes Ricardian equivalence must hold in the aggregate, but this aggregate equivalence is irrelevant for human conduct in fiscal choice. Deficit finance injects a systematic differential among current citizens in the cost of public finance, making that cost lower the weaker the degree of intergenerational altruism and the higher the rate of time preference.

In this paper I have considered public debt as an alternative to tax finance. But within existing monetary institutions, public debt creation often serves as a disguised form of money creation. The possibility of inflationary finance opens up, in turn, new avenues along which deficit finance may serve as a means by which politically dominant groups are able to impose costs on others. A complete analysis of public debt within an interest-group approach to fiscal processes will clearly have to incorporate and integrate such monetary considerations, at least under prevailing central banking institutions. ${ }^{9}$ Wherever such an analysis might lead, Ricardian equivalence will have to hold in the aggregate; yet such aggregative equivalence will be only a side show in the fiscal drama that public debt represents. 


\section{REFERENCES}

Alesina, A. and Perotti, R. 1994. "The Political Economy of Budget Deficits." IMF Staff Papers 42: 1-37.

Alt, J. and Lowrey, J. 1994. "Divided Government, Fiscal Institutions, and Budget Deficits: Evidence from the States." American Political Science Review 88: 811-28.

Backhaus, J. G. 1992. "The State as a Club: A Perspective for Public Finance in a Prosperous Democracy" Journal of Public Finance and Public Choice 10: 3-16.

Backhaus, J. G. and Wagner, R. E. 1987. "The Cameralists: A Public Choice Perspective." Public Choice 53: 3-20.

Barro, R. J. 1974. "Are Government Bonds Net Wealth?" Journal of Political Economy: 1095-1118.

Barro, R. J. 1979. "On the Determination of the Public Debt." Journal of Political Economy 87: 940-71.

Boyes, W. J., Mounts, W. S., and Sowell, C. 1998. "Monetary and Fiscal Constitutions and the Bureaucratic Behavior of the Federal Reserve." Public Finance Review 26: 548-64.

Brennan, G. and Buchanan, J. M. 1980. The Power to Tax: Analytical Foundations of a Fiscal Constitution. Cambridge: Cambridge University Press.

Buchanan, J. M. 1958. Public Principles of Public Debt. Homewood, IL: Richard D. Irwin. 
Buchanan, J. M. 1967. Public Finance in Democratic Process. Chapel Hill: University of North Carolina Press.

Buchanan, J. M. 1964. "Fiscal Institutions and Efficiency in Collective Outlay." American Economic Review, Papers and Proceedings 54: 227-35.

Buchanan, J. M. and Roback, J. 1987. "The Incidence and Effects of Public Debt in the Absence of Fiscal Illusion." Public Finance Quarterly 15: 5-25. Bulow, J. and Rogoff K. 1989. "Sovereign Debt: Is To Forgive To Forget?" American Economic Review 79: 43-50.

Calvo, G. 1988. "Servicing Public Debt: the Role of Expectations." American Economic Review 78: 647-61.

Congleton, R. 1992. "The Politics of Debt," Journal of Public Finance and Public Choice 10: 17-34.

Cukierman, A. and Meltzer, A. H. 1989. "A Political Theory of Government Debt and Deficits in a Neo-Ricardian Framework." American Economic Review 79: 13-32.

de Viti de Marco, A. 1936. First Principles of Public Finance. New York: Harcourt Brace.

Drazen A. 2000. Political Economy in Macroeconomics. Princeton, NJ: Princeton University Press.

Eaton, J. and Gersovitz, M. 1981. "Debt with Potential Repudiation: Theoretical and Empirical Analysis." Review of Economic Studies 48: 289-309.

Ferguson, J. M. (ed.) 1964. Public Debt and Future Generations. Chapel Hill: University of North Carolina Press. 
Friedman, M. 1971. "Government Revenue from Inflation." Journal of Political Economy 79: 846-56.

Grier, K. B. and Nieman, H. E. 1987. "Deficits, Politics, and Money Growth." Economic Inquiry 25: 201-14.

Grossman, H. I. and Van Huyck, J. B. 1988. "Sovereign Debt as a Contingent Claim: Excusable Default, Repudiation, and Reputation." American Economic Review 78: 1088-97.

Hettich, W. and Winer, S. L. 1999. Democratic Choice and Taxation.

Cambridge: Cambridge University Press.

Horrigan, B. R. 1986. "The Determinants of the Public Debt of the United States, 1953-1978." Economic Inquiry 24: 11-23.

Iversen, T. 1999. "The Political Economy of Inflation: Bargaining Structure or Central Bank Independence?" Public Choice 99: 237-58.

Justi, J. H. G. von. 1969. Natur und Wesen der Staaten. Darmstadt: Scientia Verlag Aalen. [Reprint from 1771 edition.]

Lerner, A. P. 1948. "The Burden of the National Debt." In L. A. Metzler (ed.), Income, Employment, and Public Policy (New York: W. W. Norton), pp. 255-75.

Mitchell, W. C. and Simmons, R. T. 1994. Beyond Politics: Markets, Welfare, and the Failure of Bureaucracy. Boulder, CO: Westview Press.

Parkin, M. 1986. "Domestic Monetary Institutions and Deficits." In J. M. Buchanan, C. K. Rowley, and R. D. Tollison (eds.), Deficits (Oxford: Blackwell), pp. 310-37. 
Persson, T. and Svensson, L. E. O. 1989. "Why a Stubborn Conservative Would Run a Deficit: Policy with Time-Inconsistent Preferences." Quarterly Journal of Economics 104: 325-45.

Ricardo, D. 1817 [1963]. Principles of Political Economy and Taxation. Homewood, IL: Richard D. Irwin.

Schumpeter, J. A. 1954. A History of Economic Analysis. New York: Oxford University Press.

Selgin, G. 1988. A Theory of Free Banking. Totowa, NJ: Rowman and Littlefield.

Selgin, G. and White, L. H. 1999. "A Fiscal Theory of Government's Role in Money," Economic Inquiry 37: 154-65.

Smith, A. 1776 [1937]. An Inquiry into the Nature and Causes of the Wealth of Nations. New York: Modern Library.

Spaventa, L. 1988. "Introduction: Is There a Public Debt Problem in Italy?" In F. Giavazzi and L. Spaventa (eds.), High Public Debt: The Italian Experience (Cambridge: Cambridge University Press), pp. 1-24.

Tabellini, G. 1987. "Central Bank Reputation and the Monetization of Deficits." Economic Inquiry 25: 185-200.

Tabellini, G. and Alesina, A. 1990.) "Voting on the Budget Deficit." American Economic Review 80: 37-49.

Toma, M. 1982.) "Inflationary Bias of the Federal Reserve System." Journal of Monetary Economics 10: 163-90. 
Thompson, E. A. 1967. "Debt Instruments in Both Macroeconomic and Capital Theory." American Economic Review 57: 1196-1210.

Tullock, G. 1967. "The Welfare Economics of Tariffs, Monopolies, and Theft." Western Economic Journal 5: 224-32.

Wagner, R. E. 1986a. "Liability Rules, Fiscal Institutions, and the Debt." In J. M. Buchanan, C. K. Rowley, and R. D. Tollison (eds.), Deficits (Oxford: Basil Blackwell), pp. 199-217.

Wagner, R. E. 1986b. "Central Banking and the Fed: A Public Choice Perspective." Cato Journal 6: 519-38.

Wagner, R. E. 1996. "Who Owes What, and to Whom? Public Debt, Ricardian Equivalence, and Governmental Form." Review of Austrian Economics 9: $143-57$.

Wagner, R. E. Forthcoming. "The Cameralists: Fertile Sources for a New Science of Public Finance, in J. G. Backhaus, ed., Founders of Modern Economy: Masstricht Lectures in Political Economy, (Cheltenham: Edward Elgar, forthcoming).

White, L. H. 1999. The Theory of Monetary Institutions. Oxford: Blackwell.

Wicksell, K. 1896. "A New Principle of Just Taxation." In Classics in the Theory of Public Finance, ed. by R. A. Musgrave and A. T. Peacock (London: Macmillan, 1958), pp. 72-118. 


\section{Endnotes}

${ }^{1}$ It can also use regulation as a nonfiscal substitute for what would otherwise be a budgetary operation. For instance, a state could pretty much abolish its education budget by requiring parents to send their children to designated schools.

${ }^{2}$ On Cameralist budgetary practice, see Backhaus and Wagner (1987). For a comparison of Justi and Smith, see Wagner (forthcoming).

${ }^{3}$ For a careful statement of this general theme, see Buchanan (1967).

${ }^{4}$ For a sampling of analyses in this vein, see Alesina and Perotti (1994), Buchanan and Roback (1987), Congleton (1992), Cuikerman and Meltzer (1989), and Tabellini and Alesina (1990).

${ }^{5}$ The importance of institutional settings for debt analysis is explored in Wagner (1986a) (1996).

${ }^{6}$ In a related line of argument, Cukierman and Meltzer (1989) model public debt as a means by which people who wish to leave negative bequests can do so, despite the prohibition against doing so privately. In their framework, debt choices are driven by intergenerational wealth redistribution, whereas here debt choices emerge out of contemporary budgetary politics.

${ }^{7}$ Such an approach to tax politics is sketched in Hettich and Winer (1999).

${ }^{8}$ For a valuable analysis of monetary institutions that has considerable relevance for the analytics of public debt explored here, see Lawrence White (1999). 
${ }^{9}$ For a small sample of work in this area, see Grier and Neiman (1987), Tabellini (1987), and Parkin (1986). 